\title{
Menulis Pandemi
}

\author{
Sunanto $\mathrm{Ng}^{1}$ \\ Deputy Editor, Indonesian Journal of Cardiology
}

O unia saat ini menghadapi situasi yang tidak pernah terjadi sebelumnya dalam sejarah manusia: pandemi COVID-19 (Gambar). Pengetahuan manusia mengenai penyakit COVID-19 secara pesat berkembang sejak laporan kasus awal dari Wuhan. ${ }^{1}$ Secara pesat, banyak laporan kasus, seri kasus, kohor dan belakangan studi mengenai COVID-19 dan tatalaksananya dilaporkan di berbagai jurnal. Beberapa jurnal esensial, seperti NEJM dan Lancet, bahkan menerbitkan isu khusus mengenai COVID-19. Pengetahuan tentang COVID-19 secara mayor boleh dikatakan berasal dari tiga klaster kohor epidemi; yaitu di China (terutama Wuhan), Italia, dan Amerika Serikat. Beberapa klaster lainnya, seperti dari Korea Selatan dan Jerman, melaporkan keberhasilan meredam perluasan epidemi.

Penyakit COVID-19 secara primer diketahui berdampak terhadap mortalitas dan morbiditas karena menyerang sistim pernafasan, yang dikenal dalam bentuk berat sebagai severe acute respiratory syndrome (SARSCoV-2). Namun, tidak hanya pernafasan, COVID-19 juga berdampak terhadap sistim kardiovaskular. Bahkan dari observasi kohor awal, pasien dengan

\footnotetext{
I Departemen Kardiologi, Universitas Pelita Harapan / Siloam
} Hospital Lippo Village, Indonesia.

\section{Koresponden:}

Sunanto Ng, Departemen Kardiologi, Universitas Pelita Harapan / Siloam Hospital Lippo Village, Indonesia

E-mail: Sunanto.ng@uph.edu masalah jantung menjadi prediktor kematian penderita COVID-19. Selain sebagai faktor pemberat, ternyata COVID-19 juga menyerang sistim kardiovaskular. Salah satunya karena ketersediaan banyak angiotensinconverting-enzyme 2 (ACE2) di sistim kardiovaskular (selain di sel pneumosit dan beberapa jenis sel organ lain). ${ }^{2}$ ACE2 adalah protein transmembran sel yang memiliki fungsi enzimatik terkait angiotensin. ACE2 secara koinsiden menjadi kunci tempel virus korona dalam proses internalisasi virus ke dalam sel. Tanpa ketersediaan ACE2 di membran sel, virus tidak dapat masuk ke dalam sel dan berkembang.

Pengetahuan tentang COVID-19 dan tatalaksana berawal secara empiris dan berkembang hingga saat ini. Laporan kohor dan seri kasus menjadi bentuk laporan ilmiah yang paling banyak dipublikasi terutama di fase awal (sekitar Januari hingga Maret). Hal ini bisa dimaklumi karena pengetahuan ilmiah harus berkejaran waktu dengan angka penyebaran dan mortalitas COVID-19 yang eksponensial. Namun interpretasi kritis terhadap laporan ilmiah tersebut tetap diperlukan dalam upaya kita memitigasi dampak COVID-19 dalam praktik sehari-hari kita. Contoh nyata, misalnya penggunaan klorokuin yang diawali dari pendekatan empiris di China, kemudian diadopsi banyak negara sebagai terapi utama. Namun, belakangan (sejak Maret) penggunaan klorokuin mulai diragukan efektifitasnya dan bahkan diperingatkan kemungkinan efek sampingnya terhadap kejadian aritmia. ${ }^{3}$ 
Indonesian Journal of Cardiology (IJC) sebagai jurnal peer kardiovaskular di Indonesia pada isu ini menerbitkan pandangan ahli dan pendapat berdasarkan tinjauan ilmiah dan pengalaman klinis terkait COVID-19. Sebagian artikel yang masuk adalah hasil tinjauan ilmiah putaka. Terdapat dua laporan kasus yang menarik terkait dampak COVID-19 terhadap sistim dan pelayanan kardiovaskular.

Dian $\mathrm{YH}$ et al secara komprehensif menyajikan tinjauan pustaka terkait dampak COVID-19 terhadap sistim kardiovaskular. Tidak hanya melalui jalur ACE2, COVID-19 juga dapat mengakibatkan komplikasi kardiovaskular melalui kejadian patofisiologi hipoksik, kerusakan (mikro)vaskular, dan atau respons inflamasi yang berlebihan. Artikel ini juga membahas potensi tatalaksana komplikasi kardiovaskular terkait COVID-19. Komplikasi kardiovaskular berupa miokarditis terkait COVID-19 menjadi salah satu isu penting. Siti EN et al menyajikan tinjauan pustaka terkait hal miokarditis. Tulisan ini memberikan panduan untuk diagnosis dan tatalaksana miokarditis terkait COVID-19. Mekanisme lain terkait komplikasi COVID-19 terhadap insidens kardiomiopati disajikan dalam tulisan ilmiah oleh Renan S. Kontroversi terkait penggunaan penghambat ACE atau angiotensinreceptor blocker juga dibahas dalam tulisan oleh Joshua $\mathrm{H}$ et al. Badai BT et al membahas peran olahraga dalam mengoptimalkan sistim imunitas yang potensial memberikan efek positif menghadapi risiko paparan virus. Pandemi COVID-19 juga memberikan tantangan tersendiri dalam pelayanan kardiovaskular terhadap pasien STEMI. Hal ini dibahas oleh Sunanto N et al.

Dyana $S$ et al memberikan perhatian khusus terhadap kemungkinan adanya pengaruh jender dalam mortalitas dan morbiditas terkait COVID-19. Secara epidemiologis, memang ditemukan angka kematian dan morbiditas adalah lebih tinggi pada laki-laki. ${ }^{4}$ Namun demikian, karakteristik epidemiologis lain yang terkait lebih kuat dalam hal mortalitas dan morbiditas COVID-19 adalah: umur $>65$ tahun, adanya penyakit jantung koroner, gagal jantung, aritmia, penyakit paru menahun, dan merokok.

Dengan dinamika COVID-19 yang cepat dan mengundang perhatian semua dokter, diharapkan muncul antusiasme untuk berpendapat secara ilmiah dan menuangkannya dalam tulisan. IJC menfasilitasi para klinisi kardiologis untuk menulis di tengah kesibukannya. Dengan tetap mengindahkan kaidah penulisan ilmiah, tulisan opini para klinisi akan diterima cepat melalui rubrik correspondence. Sidhi LP menyajikan pandangannya secara singkat mengenai bentuk proteksi yang bisa dilakukan seorang kardiologis dalam praktik pelayanan pasien. IJC mengundang para klinisi kardiologis lainnya untuk turut menyumbangkan opini ilmiah dalam bentuk tulisan.

Dalam isu ini, juga dibahas tentang pemanfaatan telemonitoring EKG (Tondas AE et al) dengan tujuan menjaga jarak fisik antara klinisi (kardiologis) dengan pasien. Salah satu cara yang efektif untuk meredam perluasan pandemi adalah memang dengan jaga jarak fisik. Tenaga kesehatan (termasuk kardiologis) merupakan populasi yang rentan untuk terpapar COVID-19 (misalnya dari pasien asimptomatis COVID-19 yang berobat jantung). Pemanfaatan tele-EKG ini mungkin dapat dipadukan dengan berkembangnya telekonsultasi dokter-pasien. Hal yang perlu dipikirkan adalah mengenai keamanan data terkait penempatan data medis di "ruang publik". Tidak lebih dari beberapa bulan yang lalu, isu privasi data menjadi topik kebijakan yang hangat tidak hanya pada skala perusahaan (mis. Facebook) namun masuk ke ranah kebijakan politik. Pandemi COVID-19 membalikkan situasi ini. ${ }^{5}$ Salah satu kebijakan yang dianggap membuat China berhasil dalam mitigasi pandemi COVID-19 adalah sistim "track and trace" individu yang terinfeksi menggunakan aplikasi di smartphone. Strategi yang secara potensi menghilangkan privasi data individual ini mulai diikuti beberapa negara seperti Singapore, Amerika Serikat dan Eropa. Isu privasi data medis dan di sisi lain - pemanfaatan teknologi komunikasi publik di bidang medis - memang belum menjadi bahasan hangat di Indonesia, namun perlu dijadikan potensi pembahasan ke depannya.

Dinamika pengetahuan tentang COVID-19 dan tatalaksananya menunjukkan keindahan dinamika ilmu pengetahuan dan pentingnya pandangan kritis dari setiap pihak yang terlibat, termasuk para kardiologis di tempat praktiknya masing-masing. Terbaru, European Society of Cardiology menerbitkan panduan untuk diagnosis dan tatalaksana penyakit kardiovaskular berkaitan pandemi COVID-19. ${ }^{6}$ PP PERKI telah mengadopsi dan menyadur panduan ini dalam Bahasa Indonesia; ${ }^{7}$ dengan tujuan untuk membantu praktisi kardiologi di Indonesia dalam pelayanan sehari-hari. 


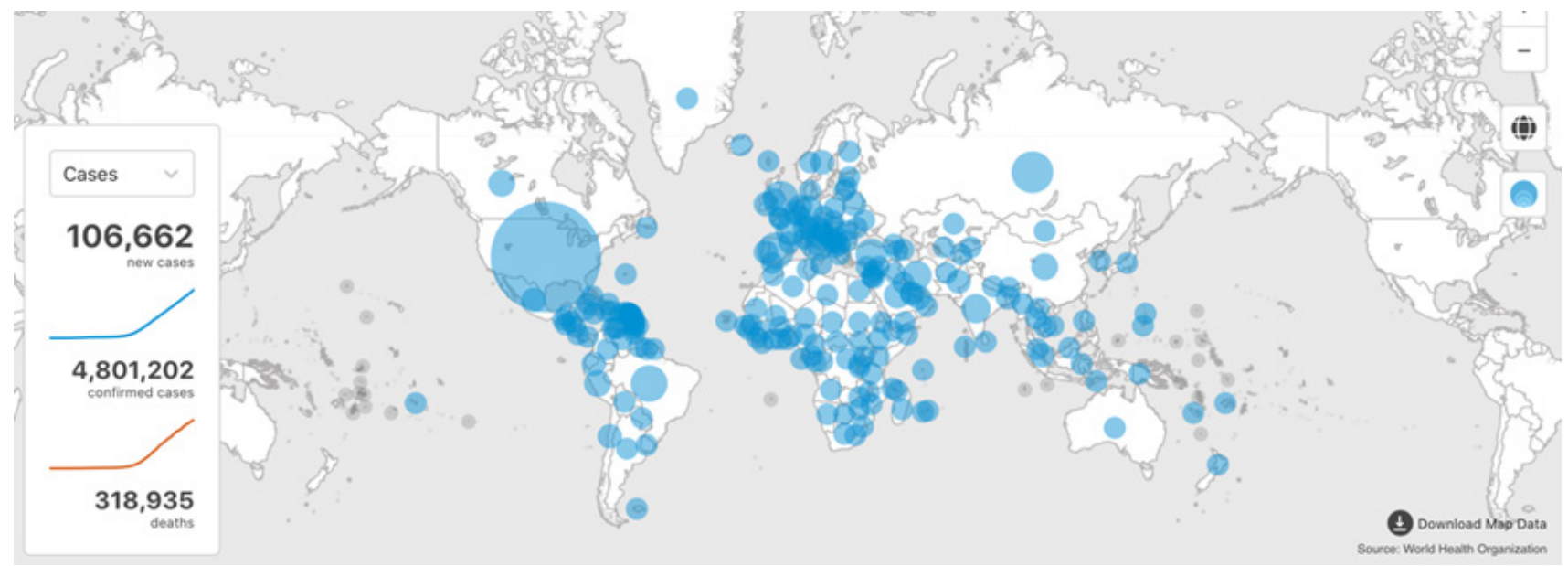

Gambar. Pandemi COVID-19 mengenai hampir seluruh negara di dunia (update WHO 20 May 2020. Diambil dari: https:// COVID19.who.int pada 20 Mei 2020).

Edisi IJC ini tidak hanya bertujuan untuk mempaparkan hasil studi ilmiah dari para rekan di berbagai daerah, namun sekaligus menjadi starter untuk mengundang para rekan lain untuk menyampaikan pendapat dan pengalaman terkait COVID-19 dan implikasinya pada kedokteran kardiovaskular. Pendapat atau respons terhadap artikel bisa disampaikan secara email ke jurnal.kardiovaskular@gmail.com atau berupa tulisan ilmiah yang dikirim melalui website www. ijconline.id. Diharapkan laporan kasus atau pandangan yang disajikan akan memperkaya keilmuan kita terkait COVID-19 dan tentunya membawakan manfaat klinis bagi pasien yang kita layani.

\section{Referensi:}

1. Zhu N, Zhang D, Wang WL, et al. A novel coronavirus from patients with pneumonia in China, 2019. N Engl J Med 2020; 382:727-733.

2. Nicin L, Abplanalp WT, Mellentin H, et al. Cell type-specific expression of the putative SARSCoV-2 receptor ACE2 in human hearts, European Heart Journal, , ehaa311, https://doi.org/10.1093/ eurheartj/ehaa311

3. FDA. FDA cautions against use of hydroxychloroquine or chloroquine for COVID-19 outside of the hospital setting or a clinical trial due to risk of heart rhythm problems. FDA Drug Safety Communication 4-24-2020.

4. Mehra MR, Desai SS, Kuy S, et al. Cardiovascular disease, drug therapy, and mortality in COVID-19. N Engl J Med. DOI: 10.1056/NEJMoa2007621.

5. Meyer D. Privacy in a pandemic. Fortune, Asia Pacific edition 2020 May; 5:12-13.

6. European Society of Cardiology. ESC Guidance for the Diagnosis and Management of CV Disease during the COVID-19 Pandemic. Last update on 21 April 2020. Accessed at https://www.escardio. org/Education/COVID-19-and-Cardiology/ESCCOVID-19-Guidance?hit=home\&urlorig=lvgn-exttemplating/

7. Perhimpunan Dokter Spesialis Kardiovaskular Indonesia. Panduan Diagnosis dan Tatalaksana Penyakit Kardiovaskular pada Pandemi COVID-19. 9 Mei 2020. Akses: http://www.inaheart.org/ upload/image/FINAL-Pan-duan_Diagnosis_dan_ Tatalaksana_Penyakit_Kardiovaskular_pada_ PANDEMI_COVID-19.pdf 